\title{
Lingwistyka audiowizualna (audiolingwistyka) - czy można wyróżnić taką gałąź w językoznawstwie? Rozważania wstępne
}

W poniższych rozważaniach podjęto próbę odpowiedzi na pytanie postawione w tytule tekstu. Do powstania artykułu przyczyniła się obserwacja działań w obszarze audiodeskrypcji, tj. techniki służącej ułatwieniu niewidomym uczestnictwa w życiu kulturowym. Nie można nie zauważyć, że w ostatnim czasie wzrosło zainteresowanie wspomnianą techniką. Także w Polsce nastąpił jej gwałtowny rozwój, co daje nadzieję na to, że wyposażanie filmów, spektakli teatralnych czy wystaw malarstwa $\mathrm{w}$ audiodeskrypcję przestanie być okazjonalnym wydarzeniem, a stanie się praktykowanym zwyczajem. Ze względu na ograniczenia formalne, zdecydowano się na zawężenie tematu do obserwacji rozwoju audiodeskrypcji w Polsce i na tej podstawie spróbowano odpowiedzieć na wspomniane wyżej pytanie.

\section{Cel i motywacja podjęcia tematu}

W poniższym tekście zajęto się rozważeniem problemu, czy można używać pojęcia „audiolingwistyka” lub „lingwistyka audiowizualna”. Motywacją podjęcia tego tematu jest przede wszystkim rosnące zainteresowanie techniką audiodeskrypcji (AD), tj. werbalnym opisywaniem sztuki w taki sposób, by umożliwić jej odbiór osobom niewidomym i niedowidzącym.

Zauważa się natężenie działań, mających na celu ułatwienie niewidomym funkcjonowania $\mathrm{w}$ codzienności oraz zapewnienie lepszego dostępu do dziedzictwa kulturowego. To znaczny postęp, który stawia także kolejne wyzwania wobec ludzi i nauki. Obecnie audiodeskrypcję może tworzyć każdy, ponieważ 
nie ma obostrzeń, które wymagałyby jakichkolwiek kwalifikacji od osoby, która chce redagować takie teksty. Nie trzeba nawet mieć ukończonego kursu z audiodeskrypcji ${ }^{1}$. Wystarczy w miarę sprawnie posługiwać się językiem. Brakuje także uniwersalnych zasad lingwistycznych, które nie tylko wyjaśniałyby, ale także argumentowały wyniki odpowiednich badań, jak pisać takie teksty użytkowe.

W tym miejscu nie podejmuje się sformułowania zasad redagowania AD, ponieważ stworzenie takich reguł to proces długofalowy, wymagający wielu badań i licznych analiz. Na łamach niniejszego tekstu spróbowano zaprojektować ujęcie tematu audiolingwistyki pod kątem ujmowania jej jako osobnej gałęzi językoznawstwa.

\section{Definicja nauki, warunki, które muszą być spełnione, by coś było uznawane za naukę}

Artykuł traktuje audiolingwistykę jako naukę zajmującą się językiem audiodeskrypcji. W celu uargumentowania takiego rozumienia terminu, poniżej zaproponowano jej podział ze względu na dostępny materiał i literaturę. Spróbowano także opisać jej miejsce w kręgu nauk humanistycznych.

Zgodnie z definicją zamieszczoną w Stowniku języka polskiego PWN [SJP] ${ }^{2}$ „nauka” to:

1) «ogół wiedzy ludzkiej ułożonej w system zagadnień; też: dyscyplina badawcza odnosząca się do pewnej dziedziny rzeczywistości»;

2) «zespół poglądów stanowiących usystematyzowaną całość i wchodzących w skład określonej dyscypliny badawczej»;

3) «uczenie się lub uczenie kogoś»;

4) «pouczenie, wskazówka»;

5) «kazanie kościelne».

Dla teksu istotne są dwa pierwsze znaczenia terminu. Następnie, ten sam słownik wyróżnia różne rodzaje nauki:

- nauka o literaturze $z o b$. literaturoznawstwo.

- nauki dedukcyjne, formalne «nauki, w których uznaje się twierdzenia jedynie wówczas, gdy się je wyprowadzi metodą dedukcji z twierdzeń już uznanych»;

- nauki empiryczne, indukcyjne «nauki, w których główną podstawą twierdzeń są zdania bezpośrednio oparte na doświadczeniu, uzasadniane również metodą indukcji»;

${ }^{1}$ Kursy takie są coraz częściej organizowane przez Katedrę UNESCO UJ w Krakowie. Są to wydarzenia cykliczne, natomiast jednorazowe szkolenia odbyły się m.in. w Muzeum Narodowym w Poznaniu oraz Muzeum Sztuki i Pałacu Herbsta w Łodzi.

${ }^{2}$ http://sjp.pwn.pl/szukaj/nauka [dostęp 2.05.2013]. 
- nauki humanistyczne «nauki, których przedmiotem badań jest człowiek jako istota społeczna i jego wytwory»;

- nauki idiograficzne «nauki ograniczające się do ustalania, opisu i wyjaśniania konkretnych faktów jednostkowych»;

- nauki nomotetyczne, nomologiczne «nauki zajmujące się wykrywaniem prawidłowości i formułowaniem ogólnych praw naukowych»;

- nauki normatywne «nauki, których głównym zadaniem jest ustalenie tego, co być powinno, a nie tego, co jest»;

- nauki polityczne $z o b$. politologia.

- nauki przyrodnicze «nauki, których przedmiotem badań są zjawiska przyrody»;

- nauki społeczne «nauki zajmujące się społeczeństwem»;

- nauki ścisłe «nauki matematyczne i przyrodnicze»;

- nauki wyzwolone «w średniowieczu: gramatyka, dialektyka, retoryka, muzyka, arytmetyka, geometria i astronomia»;

- filozofia sztuki, nauki, kultury itp. «nauka zajmująca się ogólnymi rozważaniami na temat istoty i struktury sztuki, nauki, kultury itp.».

Idąc tym tropem, ,językoznawstwo", będące hiperonimem dla językoznawstwa audiowizualnego, znajduje się w kręgu nauk wyzwolonych, zgodnie z rozumieniem:

NAUKA $\rightarrow$ NAUKA WYZWOLONA $\rightarrow$ GRAMATYKA (też JĘZYKOZNAWSTWO)

Szerszego komentarza wymaga ulokowanie proponowanej audiolingwistyki w kręgu nauk językoznawczych.

\section{Gałęzie językoznawstwa}

SJP podaje definicję językoznawstwa jako ,nauki o języku”. Szersze rozróżnienie podaje pod hasłem ,lingwistyka”:

- lingwistyka $z o b$. językoznawstwo ${ }^{3} \cdot$ lingwistyczny $\bullet$ lingwistycznie $\bullet$ lingwista

- lingwistka;

- lingwistyka antropologiczna $z o b$. etnolingwistyka ${ }^{4}$;

${ }^{3}$ «nauka o języku» (SJP), http://sjp.pwn.pl/szukaj/j\%C4\%99zykoznawstwo [dostęp 2.05.2013].

4 «dział lingwistyki zajmujący się badaniem związków między językiem a kulturą» (SJP), http://sjp.pwn.pl/szukaj/etnolingwistyka [dostęp 2.05.2013]. 
- lingwistyka kognitywna $z o b$. kognitywizm;

- lingwistyka tekstu $z o b$. gramatyka tekstu ${ }^{6}$.

Współcześnie, poza cytowanymi, wyróżnia się także: psycho-, socjo-, pragma-, neurolingwistyki, gdzie, za SJP, psycholingwistyka ${ }^{7}$ to «nauka zajmująca się procesami psychologicznymi związanymi z przetwarzaniem informacji językowych przez człowieka», socjolingwistyka ${ }^{8}$ «nauka zajmująca się funkcjonowaniem języka w społeczeństwie», pragmalingwistyka / pragmatyka ${ }^{9}$ «dział językoznawstwa, którego przedmiotem są społeczne i sytuacyjne warunki funkcjonowania języka oraz cele, jakie mówiący chce osiągnąć przez użycie określonych wyrazów i wyrażeń», neurolingwistyka ${ }^{10}$ «dziedzina lingwistyki zajmująca się badaniem mowy w ścisłym powiązaniu z procesami zachodzącymi w mózgu».

Wymienione powyżej terminy są rejestrowane w SJP, a zakres definicji zaznacza obszar, którym zajmuje się dana lingwistyka. Można przewidywać, że wraz z rozwojem badań, specjalizacje gałęzi językoznawstwa będą się mnożyć. Coraz częściej słyszy się także o teolingwistyce, która nie doczekała się jeszcze osobnego artykułu hasłowego, ale jest wymieniana przez językoznawców zajmujących się, szeroko rozumianym, językiem religijnym ${ }^{11}$.

\section{Audiolingwistyka - źródłosłów, propozycja podziału (leksyka z konkretnych rodzajów sztuki / leksyka techniczna), uzasadnienie bazą materiałową}

Źródłosłowu dla proponowanego terminu ,audiolingwistyka” należy szukać w połączeniu leksemów: „audio” + „lingwistyka”, gdzie „audio”, za SJP, rozumie się jako audio- [wym. auxdio] ${ }^{12}$ "pierwszy człon wyrazów złożonych wskazujący na ich związek znaczeniowy ze słuchem, słyszeniem, dźwiękiem», natomiast

${ }^{5}$ «kierunek we współczesnym językoznawstwie, który odwołując się do psychologii, socjologii i innych dyscyplin, zajmuje się opisem języka uwikłanego w kontekst kulturowy i badaniem, w jaki sposób w języku odzwierciedla się rzeczywistość» (SJP), http://sjp.pwn.pl/slownik/2563777/ kognitywizm [dostęp 2.05.2013].

${ }^{6}$ «dyscyplina badająca strukturę i ogólne zasady budowy tekstu» (SJP), http://sjp.pwn.pl/szukaj/gramatyka\%20tekstu [dostęp 2.05.2013].

7 http://sjp.pwn.pl/szukaj/psycholingwistyka [dostęp 2.05.2013].

${ }^{8} \mathrm{http}: / /$ sjp.pwn.pl/szukaj/socjolingwistyka [dostęp 2.05.2013].

9 http://sjp.pwn.pl/szukaj/pragmatyka [dostęp 2.05.2013].

${ }^{10} \mathrm{http}: / /$ sjp.pwn.pl/szukaj/neurolingwistyka [dostęp 2.05.2013].

${ }^{11}$ Badania nad językiem religijnym prowadzone są w ośrodkach m.in. w Lublinie (KUL), Warszawie (UKSW) i Poznaniu (UAM). Ośrodek poznański zainicjował cykliczną konferencję: Język religijny dawniej i dziś, która odbywa się co dwa lata i stanowi okazję do refleksji nad ewolucją języka, którym dziś mówi się o sacrum.

12 http://sjp.pwn.pl/szukaj/audio [dostęp 2.05.2013]. 
„lingwistyka” - jako naukę o języku. Po połączeniu znaczenia obu członów otrzymuje się znaczenie ,audiolingwistyki” (lub „lingwistyki audiowizualnej”) jako językoznawstwa zajmującego się opisem słownika i gramatyki tekstów związanych z dźwiękiem i słuchem. Ściślej rozumie się audiolingwistykę jako wiedzę językową mającą zastosowanie $\mathrm{w}$ audiodeskrypcji. Lingwistykę audiowizualną można traktować jako pogranicze językoznawstwa, łączące elementy, m.in. psycho-, socjo- i pragmalingwistyki.

\section{Audiodeskrypcja}

Audiodeskrypcja jest głównym powodem, dla którego pomyślano o tym, by wyróżnić audiolingwistykę, dlatego w tym miejscu warto zatrzymać się przy tym pojęciu. Żaden ze słowników języka polskiego ani słowników wyrazów obcych nie notuje hasła ,audiodeskrypcja”. Na potrzeby tekstu uznaje się ją jako technikę opisywania sztuki i różnego rodzaju wydarzeń, np. kulturalnych $i$ sportowych, stworzona dla osób niewidomych i niedowidzących. Mowa zarówno o sztuce filmowej, teatralnej, jak i plastycznej oraz architektonicznej. W kręgu opisywanych wydarzeń sprawdzają się opisy wydarzeń sportowych oraz szlaków dla zwiedzających. Na dzień dzisiejszy można wyróżnić kilka zasad redagowania opisów na potrzeby osób niewidomych. Ze względu na ograniczenia formalne, aspekt ten nie będzie rozwijany w niniejszym tekście ${ }^{13}$.

Dotychczasowe projekty, mające na celu udostępnienie sztuki osobom niewidomym i niedowidzącym, pozwalają zebrać na tyle okazały materiał, że można wyróżnić w nim rodzaje sztuki, które najchętniej są opisywane.

W obrębie tego rozróżnienia prym wiedzie AD filmowa i teatralna, którą jako pierwszą zaczęto praktykować zarówno na świecie ${ }^{14}$, jak i w Polsce ${ }^{15}$. Wraz z popularyzacją techniki i coraz częstszym jej wykorzystywaniem w projekcjach filmowych i teatralnych, zaczęto myśleć o tym, co jeszcze można opisywać. Okazało się, że AD sprawdza się zarówno w sztukach multimedialnych, jak i w malarstwie. Co więcej, o ile w filmie i teatrze niewidomi mogą korzystać z dialogów

${ }^{13}$ Są to ogólne zasady, o których można przeczytać w standardach tworzenia AD, np. [Szymańska, Strzymiński, 2010]; [Trzeciakiewicz, druku] oraz publikacje obcojęzyczne, np. ITC Guidance On Standards for Audio Description oraz A Comparative Study of Audio Description Guidelines Prevalent in Different Countries. Więcej źródeł podano w publikacji [Szymańska, Strzymiński, 2010: 6-7].

${ }^{14}$ AD wywodzi się ze Stanów Zjednoczonych, gdzie uruchomiona została w 1981 r. w Waszyngtonie w Arena Stage dzięki działaniom państwa Margaret i Cody’ego Pfanstiehl [Szymańska, Strzymiński, 2010: 7].

15 Pierwszy pokaz odbył się w Białymstoku w 2006 r., była to projekcja filmowa Michała Kwiecińskiego Statyści wyemitowana w kinie Pokój. 
bohaterów i dźwięków w tle, o tyle sztuka statyczna nie jest dostępna dla nich w żaden sposób. Jedyną możliwością poznania sztuki statycznej jest zwerbalizowanie treści dzieła.

Dziś opisuje się już nie tylko sztuki multimedialne, obrazy i rzeźby, ale także architekturę ${ }^{16} \mathrm{i}$ wydarzenia sportowe ${ }^{17}$. AD do każdego z wymienionych obiektów i widowisk rządzi się swoimi prawami. W opisach filmów i przedstawień AD będzie dodatkową ścieżką dźwiękową, która informuje o tym, co dzieje się w tle. Ze względu na to, że powinna się mieścić między dialogami, musi być zwięzła. Na opowiadanie o tym, jak wyglądają postaci, przeważnie brakuje czasu. AD tego typu musi być narracją sprawozdawczą, prowadzącą wyobrażenie widza od miejsca do miejsca.

W przypadku sztuki statycznej, tj. malarstwa, rzeźby i architektury, znika problem obostrzeń czasowych, gdyż nie ma dialogów i odgłosów w tle. W takiej AD można pozwolić sobie na bardziej wnikliwą analizę tego, jak wygląda dane dzieło/obiekt, co przedstawia, jak je zbudowano. Taka swoboda nie może jednak doprowadzić do rozbudowywania opisów i wdawania się w szczegóły, które mogłyby zmęczyć słuchającego, a nawet wprowadzić w błąd lub sprawić, że odbiorca poczuje się zagubiony w dużej liczbie elementów, na których trzeba się skupić.

W Polsce wydarzeniami sportowymi, opisywanymi niewidomym są mecze piłki nożnej. Audiodeskrypcja meczu polega na tym, by zapoznać niewidomego już z tym, co dzieje się zanim drużyny rozpoczną grę, tzn. komentator opisuje zachowanie zawodników wchodzących na boisko, rozstawienie graczy na boisku i wszystko, co pojawia się na ekranie, a co nie wymaga komentarza dla widzących kibiców. Opis samej gry nie różni się wiele od komentarzy sportowych i jest on wykonywany najczęściej przez radiowców, którzy znają się na piłce nożnej. Laik mógłby mieć problemy z terminologią piłkarską taką jak chociażby rzut rożny, rzut karny, pole karne, faul itd. Osoba opisująca mecz musi dbać o to, by nie odbiegać od tematu, nie może pozwalać sobie na ujawnianie swoich emocji i ,podpowiadanie" zawodnikom, co mają zrobić i do kogo podać piłkę. Ze względu na dynamikę, opisywanie meczów wymaga ciągłego skupienia, dlatego najczęściej w opisie meczu biorą udział dwie osoby.

Lingwistykę audiowizualną można traktować jako pogranicze językoznawstwa łączące w sobie elementy nauk, wracając do wyróżnień cytowanych wcześniej za SJP, empirycznych, humanistycznych, społecznych, ścisłych oraz filozofii sztuki i kultury.

Empiryczna, ponieważ opisy tworzone są w oparciu o doświadczenie i wiedzę o świecie autora AD, humanistyczna, ponieważ opisuje twórczość człowieka,

${ }^{16}$ Np. Szlak Ludwika Zamenhoffa w Białymstoku.

17 Mecze piłki nożnej, której opisy zainicjowała Fundacja KATARYNKA. Opisy można usłyszeć po włączeniu odpowiedniej funkcji na pilocie do telewizora. Mecze bywają też opisywane na żywo ze stadionu we Wrocławiu albo ze Stadionu Narodowego w Warszawie. 
społeczna, gdyż służy opisowi czegoś, co służy społeczeństwu, ścisła, ponieważ opisy powinny być zwięzłe i odnosić się do tego, co widać. Założenie dotyczące filozofii kultury i sztuki także zostaje spełnione, gdyż można powiedzieć, że audiolingwistyka niejako traktuje o strukturze sztuki.

Chcąc uporządkować przedstawiony materiał, można spróbować podzielić audiodeskrypcję ze względu na zakres tematyczny sztuki, do której się odnosi. Tak to w obrębie całej audiolingwistyki znalazłyby się następujące kategorie:

- a. filmu - dodatkowa ścieżka dźwiękowa opisująca to, co dzieje się na ekranie, ale nie nachodząca na wypowiedzi bohaterów oraz istotne dla akcji dźwięki; w sytuacji, gdy jest to projekcja niema ${ }^{18}$, AD będzie stanowiła narrację główną o charakterze sprawozdawczym;

- a. teatru - dodatkowa ścieżka dźwiękowa tworzona na żywo, informująca o tym, co dzieje się na scenie;

- a. wydarzeń sportowych - relacja na żywo, komentująca, co dzieje się na boisku, bez zdradzania emocji towarzyszących komentatorom;

- a. sztuki statycznej - opis danego dzieła pod względem treści, kolorystyki i techniki wykonania; dzieli się na:

- a. malarstwa,

- a. rzeźby,

- a. architektury.

Powyższe kategorie pozwalają wyróżnić pola semantyczne, wokół których będzie się budowało leksykon pojęć charakterystycznych dla każdej z nich. Ze względu na ograniczenia formalne niniejsze rozważania skupiają się jedynie na propozycji obszarów tematycznych. Nie podejmuje się tutaj rejestrowania konkretnych leksemów, które można włączyć do danego pola ${ }^{19}$.

W niniejszym tekście wyróżnia się pięć głównych pól semantycznych i uznaje się je jako obligatoryjne w każdym opisie kierowanym dla osób niewidomych. Odwołując się do podziału audiodeskrypcji ze względu na zakres tematyczny sztuki $^{20}$, można wyróżnić zakresy znaczeniowe traktujące o:
a) czasie powstania dzieła/epoce,
b) stylu i gatunku/rodzaju dzieła/technice, w której zostało wykonane,
c) temacie/tytule (np. to, co dzieło przedstawia),
d) autorze,
e) leksyce charakterystycznej.

${ }^{18} \mathrm{~W}$ przeciwieństwie do filmów z dialogami, produkcje nieme w żaden sposób nie są dostępne osobom niewidomym, jedyne z czego tacy widzowie mogą korzystać, to ścieżka dźwiękowa stanowiąca tło do przedstawianych scen.

19 Przedstawiony podział stanowi propozycję i powstał jako klasyfikacja umowna na podstawie obserwacji dostępnego materiału.

${ }^{20}$ O których mowa była wcześniej. 
Graficznie podział ten przedstawia się w następujący sposób:

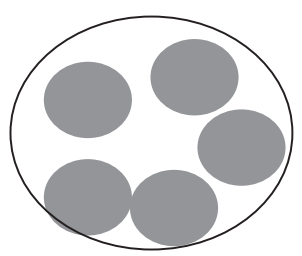

Legenda:

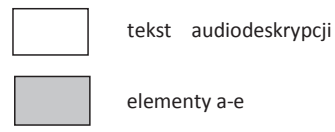

Podział ten został stworzony bez odniesień do sposobu kadrowania, ponieważ ten problem podobnie jak ukształtowanie narracji w AD zależą od specyfiki dzieła ${ }^{21}$. Każdy z obszarów tematycznych składa się z mniejszych pól semantycznych. Zależą one od tematu dzieła sztuki, dlatego ze względu na różnorodność wytworów i tematów, nieuzasadnione wydaje się wyliczanie elementów, które zalicza się do mniejszych obszarów znaczeniowych. Już w odniesieniu do samego malarstwa leksyka będzie zróżnicowana ze względu na temat dzieła, tzn. innego słownictwa wymaga obraz przedstawiający scenę batalistyczną, rodzajową czy martwą naturę itd.

Chcąc mówić o lingwistyce audiowizualnej jako nowej gałęzi językoznawstwa, nie można nie powiedzieć o obudowie teoretycznej tego tematu. Stosując podział na literaturę podmiotu i przedmiotu, do tej pierwszej zalicza się wszelkie skrypty i opisy dzieł powstałe na potrzeby projekcji i wystaw. Dopiero analizy skryptów, wyprowadzenie wniosków i wyposażenie ich w obudowę teoretyczną oraz literaturę przedmiotu da podstawy do ukucia terminu audiolingwistyki.

Nie sposób wymienić tutaj wszystkich tytułów, które mogą tworzyć wspomnianą obudowę teoretyczną. Można jednak wymienić kręgi tematyczne, w obrębie których należy poruszać się, pracując nad metodologią audiolingwistyki. Bez wątpienia pomocna przy tworzeniu opisu lingwistyki audiowizualnej jest nie tylko literatura stricte językowa, ale także psychologiczna, socjologiczna, historyczno-sztuczna i, w sposób szczególny, tyflopedagogiczna oraz dotycząca samej techniki AD.

Literatura lingwistyczna pomoże przy badaniu systemu językowego i gramatyki audiodeskrypcji. Literatura psychologiczna i socjologiczna będzie po-

${ }^{21}$ Inaczej będzie przebiegało kadrowanie i przenoszenie uwagi na obrazie, inaczej w odniesieniu do rzeźby oraz inaczej, gdy opisuje się architekturę. 
mocna przy badaniu zachowań odbiorców i ich reakcji na dany opis. Tutaj warto nadmienić, że ciekawe wnioski może dać, m.in. badanie percepcji kolorów, w związku z czym niezbędna okaże się literatura na temat psychologii barw. Tytuły traktujące o historii sztuki dadzą bazę terminologiczną nie tylko z zakresu filmu i teatru, lecz także malarstwa, rzeźby i architektury. Ukształtują też pojęcie na temat ram czasowych i cech charakterystycznych poszczególnych kierunków w sztuce.

Bibliografia tyflopedagogiczna zwróci uwagę na to, jak adaptować treści na potrzeby osób niewidomych oraz będzie stanowić kontekst do całokształtu badań audiolingwistycznych. Podobnie z literaturą o samej AD, która ujmuje problem globalnie, bez wchodzenia w niuanse, takie jak język, styl czy gramatyka tworzonych opisów ${ }^{22}$.

\section{Perspektywy rozwoju}

Zauważa się coraz większe zainteresowanie nie tylko tym, by tworzyć skrypty, lecz także ich jakością. W związku z tym prowadzi się badania mające na celu sprawdzenie odbioru skryptów wśród potencjalnych czytelników. Prowadzone obecnie (polskie i światowe) badania dotyczą głównie percepcji AD filmowej i odbioru różnych opisów ${ }^{23}$. W niniejszym tekście refleksji poddano językowe ukształtowanie $\mathrm{AD}$ dla różnego rodzaju sztuki.

Jako że rośnie liczba skryptów zarówno filmowych, jak i dla sztuki statycznej, istnieje szansa, że w przyszłości mówienie o ,audiolingwistyce" będzie naturalne. Być może badania pozwolą wyróżnić cechy charakterystyczne dla poszczególnych rodzajów audiolingwistyk. Problemy, które powinna podjąć taka gałąź językoznawstwa to np. badanie percepcji kolorów, sposoby definiowania pojęć, kadrowanie czy ukucie definicji interpretacji oraz zbadanie semantyki i wyodrębnienie leksyki głównych pól semantycznych.

Jak już wspomniano, nie sposób dokonać rejestru wszystkich możliwych leksemów, które mogą pojawić się w AD. Jest to zbiór otwarty i równie szeroki, jak szeroka jest tematyka dzieł podejmowanych przez autorów. Można jednak pokusić się o stworzenie „worka lingwistycznego” z pojęciami odnoszącymi się do samej audiodeskrypcji. Zakres takiego zbioru obejmowałby m.in. następujące

22 Jeśli chodzi o język i styl, to zazwyczaj powtarza się, że opisy mają być zbudowane z krótkich zdań i nie mają zawierać interpretacji. Odpowiedź na pytanie, czy rzeczywiście należy zawsze unikać interpretacji jest oddzielnym problemem, dlatego z racji wspomnianych ograniczeń, pozostawi się go bez komentarza.

${ }^{23}$ Takie badania były prowadzone przez Agnieszkę Chmiel i Iwonę Mazur z Uniwersytetu im. Adama Mickiewicza oraz przez zespół Agnieszki Szarkowskiej AVTV LAB z Uniwersytetu Warszawskiego. 
terminy [Szymańska, Strzymiński 2010: 4]: audiodeskrypcja, audiodeskrybować, audiodeskryber/audiodeskryptor ${ }^{24}$, deskryptor, skrypt, lektor, produkcja audiowizualna.

\section{Zakończenie}

Tekst ten nie miał na celu wyczerpać tematu audiolingwistyki. Chodziło przede wszystkim o to, by zwrócić uwagę i zastanowić się, czy stosowne byłoby używanie proponowanego terminu. Podjęto też próbę wstępnej klasyfikacji, charakterystyki wspomnianej gałęzi językoznawstwa oraz jej obudowę metodologiczną i miejsce wśród dyscyplin językoznawczych.

Nie ulega wątpliwości, że wszystko co nowe, aby zyskać akceptację, wymaga czasu. Tak samo z audiolingwistyką - musi wypracować sobie obudowę teoretyczną na podstawie analiz dostarczanych skryptów. Choć sama AD jest techniką rozwijającą się w Polsce zaledwie od siedmiu lat, dziś termin ten nie wywołuje takiego zdziwienia jak chociażby trzy czy pięć lat temu, co więcej - jest częściej praktykowana. To pozwala mieć nadzieję, że refleksja językowa nad powstającymi tekstami sprawi, że audiodeskrypcja będzie na coraz wyższym poziomie.

Mając na uwadze wnioski prezentowane w tekście, na pytanie zawarte w tytule należy odpowiedzieć twierdząco. Można mówić o audiolingwistyce, czyli nauce o języku audiodeskrypcji, bowiem istniejący materiał dostarcza narzędzi, które mogą służyć budowie warsztatu metodologicznego dla takiej gałęzi językoznawstwa. Co więcej, niewykluczone, że sama audiodeskrypcja zacznie być traktowana jako nauka ${ }^{25}$ z pogranicza tyflopedagogiki, dostarczająca wiedzy na temat percepcji i psychologii osób niewidomych ${ }^{26}$.

\section{Bibliografia}

Brzeziński J. [2012], Metodologia badań psychologicznych, Warszawa.

http://www.ofcom.org.uk/static/archive/itc/uploads/ITC_Guidance_On_Standards_for_Audio_Description.doc

${ }^{24}$ Osoba tworząca audiodeskrypcję. Obecnie funkcjonują obie formy i obie są uważane za poprawne. By rozstrzygnąć fortunność ich użycia, należałoby dokonać rejestru występowania tych terminów w tekstach teoretycznych. Jest to zagadnienie na tyle szerokie, że warto poświęcić mu osobny tekst (propozycja własna).

${ }^{25}$ Temu zagadnieniu warto poświęcić oddzielny tekst i omówić szerzej zarówno pod kątem metodologicznym, jak i teoretycznym. By usystematyzować rozważania teoretyczne można odwołać się do podręcznika Jerzego Brzezińskiego, Metodologia badań psychologicznych, Warszawa 2012.

${ }^{26} \mathrm{~W}$ takim ujęciu audiodeskrypcja będzie stanowiła hiperonim w stosunku do audiolingwistyki, gdyż będzie wobec niej pojęciem nadrzędnym. 
ITC Guidance On Standards for Audio Description.

Rai Sonali, Greening Joan, Petre Leen [2010], A Comparative Study of Audio Description Guidelines Prevalent in Different Countries, London: RNIB.

Szymańska B., Strzymiński T. [2010], Obrazy słowem malowane, Białystok.

Trzeciakiewicz M. (red.), Audiodeskrypcja w teorii i praktyce (podręcznik w druku).

www.sjp.pwn.pl 